\title{
Bacurau flies at dusk: film, viral cultural politics, Covid-19, hauntings, and futures
}

o bacurau voa no crepúsculo: filme, cultura política viral, Covid-19, assombrações e futuros

\section{Michael M. J. Fischer}

\section{(2) OpenEdition \\ Journals}

Electronic version

URL: http://journals.openedition.org/aa/7681

DOI: 10.4000/aa.7681

ISSN: 2357-738X

\section{Publisher}

Programa de Pós-Graduação em Antropologia Social (UnB)

Printed version

Number of pages: 166-189

ISSN: 0102-4302

\section{Electronic reference}

Michael M. J. Fischer, "Bacurau flies at dusk: film, viral cultural politics, Covid-19, hauntings, and futures", Anuário Antropológico [Online], v.46 n.1 | 2021, Online since 03 January 2021, connection on 28 April 2021. URL: http://journals.openedition.org/aa/7681 ; DOI: https://doi.org/10.4000/aa.7681

\section{cc) (1) $\odot$}

Anuário Antropológico is licensed under a Creative Commons Atribuição-Uso Não-Comercial-Proibição de realização de Obras Derivadas 4.0 International. 


\title{
Bacurau flies at dusk: film, viral cultural politics, Covid-19, hauntings, and futures
}

\author{
O bacurau voa no crepúsculo: Filme, cultura politica viral, Covid-19, \\ assombrações e futuros
}

DOI: https://doi.org/10.4000/aa.7681

\begin{abstract}
Michael M. J. Fischer - Massachusetts Institute of Technology - Estados Unidos
The Andrew W. Mellon Professor in the Humanities and Professor of Anthropology and Science and TechnoFutures (2009); Emergent Forms of Life (2003), Art and Emergent 21st Century Common Sense (forthcoming).
\end{abstract}

This essay is one of a series on the arts and forms of emergent common sense in the globally interconnected, politically-semiotically-media fraught, Anthropocenic twenty-first century. The arts restlessly play hopscotch with temporalities and locations. Since the days of Third Cinema, auteur cinema, and national cinemas, films have attempted complex strategies, often mobilizing local and international genre film forms subversively against themselves to create a cinema of laughter, self-recognition, and critique. The 2019 Cannes Jury Award-winning film Bacurau provides an addictively detailed, yet globally accessible, intervention into the struggles over Covid-19, authoritarianism, and erosion of indigenous, black, and other marginalized citizens' rights. As such, it is a kind of social drama that encompasses expanding breaches in the social fabric beyond its text and reworking temporal relations between pasts and futures.

Bacurau. Aesthetics and critique. Social drama and cultural politics. Hauntings and futures. Brazil-US dyad. Covid-19.
Este ensaio faz parte de uma série sobre as artes e formas de senso comum emergentes no globalmente interconectado, intensamente político-semiótico-midiático e antropocênico século XXI. As artes brincam incessantemente de amarelinha com temporalidades e espacialidades. Desde os dias do Terceiro Cinema, do cinema de autor e dos cinemas nacionais, os filmes têm experimentado estratégias complexas, muitas vezes mobilizando gêneros cinematográficos locais e internacionais subversivamente, contra si mesmos, para criar um cinema de riso, autorreconhecimento e crítica. Bacurau, filme vencedor do Prêmio do Júri de Cannes de 2019, oferece uma intervenção detalhada, mas acessível globalmente, nas lutas em relação a Covid-19, autoritarismo e erosão dos direitos indígenas, negros e de outros cidadãos marginalizados. Dessa forma, é uma espécie de drama social que abarca a expansão das brechas no tecido social para além de seu texto e o retrabalho das relações temporais entre passados e futuros.

Bacurau. Estética e crítica. Drama social e política cultural. Assombrações e futuros. Díade Brasil-EUA. Covid-19. 


\section{Exergue}

This essay is one of a series on the arts and forms of emergent common sense in the globally interconnected, politically-semiotically-media fraught, Anthropocenic twenty-first century - a stage on which, and within which, anthropology is positioned often as a target because it can deploy potent ethnographic tools to analyze, clarify and make legible the social dramas surrounding films, pandemics, global protests, and popular culture interferences ${ }^{1}$. In the current wave of reactionary and authoritarian moves to undo democratic advances - that have been unveiled with deadly intensity by the Covid-19 pandemic, exposing old and new social polarizations - the Brazil-US dyad provides a key ethnographic locus, within which the film Bacurau provides a complex lens of both hauntings and futures ${ }^{2}$.

Bacurau deploys a transnational mix of cultural genres, technological projection, and mirrorings of deep social polarizations. Its receptions expand the double consciousness between realism and symbolic logic that semiotically structures politics in Brazil, the United States, and elsewhere. It becomes, thus, also a social drama, stimulant, and hallucinogen that ignites flashpoints of clarity and condensations of meaning in singular resonant and memorable images. Tropicália, Cinema Novo, and Movimento Antropofágico are historical referents, but the social drama in Brazil (and its interactions with those in the U.S. and elsewhere) continues to unfold today in a series of scandals, murders, the viral spread of Covid-19, and the viral interpellation of global genres, imperialisms, and racisms ${ }^{3}$. It unfolds in American film fantasies of the hunt, the safari, and the science fiction genre of alien invasions which are cultural referents in the film, and in the violence of mass shootings and police violence in the U.S. alluded to in the film, and even so-called fifth-generation hybrid warfare in Brazil and elsewhere ${ }^{4}$.

Truth in art, as in psychoanalysis, is the triggering of further examples (social dramas). It can involve passionate reactions and competing decodings of signs, images, and semantics (filmic judgment). To judge such artwork or cinema interventions merely by the rules of genre is to demand not to know. To insist on a modicum of cultural inquisitiveness is an act of citizenship, both national and transnational.

The hope of "Third Cinema" in the 1960s and 70s (in opposition to, or at least to supplement, both Hollywood and auteur cinema) was to build a cinema outside the commodity system, to figure out how to turn filmic discourses into sustained movements for political and social reconstruction of society that are neither just reform that can be recuperated by the commodity system, nor simplistic revolution that has no grassroots social organizational preparation (Solanas; Getino, 1969). Since then, films have attempted more complex strategies, often mobilizing genre film forms subversively against themselves to create a cinema of laughter, recognition, and critique.

Brazil is rushing to catch up with the U.S. in Covid-19 cases (5.18 million cases and 153,000 deaths in the official count by October 15, 2020; U.S. 8.04 million and
Acknowledgements: With many thanks to my beta readers and listeners: Mariza Peirano, Luisa Reis Castro, João Biehl, Adriana Petryna, Maria Beldi de Alcântara, the participants of the Harvard Friday Morning Seminar in Medical Anthropology, and the two anonymous reviewers.

1 By linguistically fraught, I am thinking of such diagnoses as digitally enabled "post-truth" conditions of "equiprobability, where virtually any statement can be challenged at very low, or no, cost" (Cesarino, 2020) and cryptographic models of proxy social media to disappear sources, as part of hybrid warfare and politics, inserted into national political systems (Leirner, 2020). On Anthropology as a target, see Neiburg and Ribeiro (2002), Cabral de Oliveira and Marini (2020), and Cavignac (2020); but also, more generally, the role of Anthropology in promoting what Almeida (2020) calls "compensatory politics" (investing in those who have had low social and economic capital) seen as inimical to radical neoliberalism.

2 I use Bacurau for the village-place name; and italicized Bacurau for the film name.

3 On social drama, see Max Gluckman (1963) and Victor Turner (1957 and his subsequent work on ritual processes and, with Richard Schechner on theater and performance arts), but on social drama and other arts such as novels and cartoons, inter alia, see Fischer (1990, 2009).

4 It is possible to view what I will call the safari game as an exercise in the hybrid warfare in Brazil as brilliantly described by Piero Leirner (2020). The clue in the film might be the identity of the Brazilian collaborator who turns out to have a police department identity card on him when he is killed. Another disturbing strand of the Brazil-U.S. dyad is the Bolsonaro-Trump campaigns against Cuban doctors in Brazil (especially the 8,000 serving the Indigenous communities of the Amazon) leading to their 
218,000 respectively). Brazil's president, like the American one, proclaims masks, physical distancing, testing, and tracing are unnecessary, that hydroxychloroquine is a prophylactic, and that everyone should just get back to work. Brazil's president has actively supported the disregard of Indian land and health rights (despite hundreds of Covid-19 deaths among indigenous people and suspicions by their leaders that the government is using the pandemic to help clear the land of Indians ${ }^{5}$ ); he promotes the invasion of the Amazon by farmers and miners in the cause of economic development, and the invasion of the coastal uplands of the Tupinamba by luxury hotel developers. The fires of deforestation and the clearing of the Amazon rainforests threatens one of the great lungs of the earth, contributing to the acceleration of climate change ${ }^{6}$.

\section{Temporalities of Film Production and Reception}

Now is the time for the bacurau/ the jaguar dances forward/ the capoeira and babau dance/ a feast of fear and

terror/

phantoms haunt the wake/ punching holes in the trunk of night the woodpecker's beak/ spells are floating in the air/ the work of an evil sorcerer/ charms and jinxes dreamed up at the xang ${ }^{7}$ in Nicolau's.

- Dirge at the funeral of Carmelita

A film from the northeast of Brazil comes like an entertaining but ever-deepening and thought-provoking puzzle and layered metaphor just before the coronavirus [SARS-CoV-2 or Covid-19] pandemic breaks over the globe, beginning in China, and arriving in Brazil two months later, revealing and exacerbating the polarizations in society ${ }^{8}$. Not only did reality catch up with the film script, supercharging it in the editing, but reality continued to extend the film's time frame beyond its completion. As director Kleber Mendonça Filho noted at Cannes (in the 2019 press conference), while the film is set in the near future, it is really about the repetitions in Brazilian history, and its social or politico-economic atmosphere is one that affects not only Brazil. Even more sharply, Silvero Pereira, the actor who plays Lunga in the film, says in an interview: "This isn't specifically about the current government. It is about the government that we've always had" (Rubenstein, 2020). It is a theme that Black or African-American commentators also say about the Black Lives Matter protest marches and demonstrations that spread across America after the murder of George Floyd on 25 May 2020 by a white policeman in Minneapolis, and the disparities in Covid-19 illnesses, deaths, and ability to practice prevention. withdrawal, and the defunding of the Pan American Health Organization with its 120 years of experience fighting pandemics in Latin America (Kirpatrick; Cabrera, 2020).

5 COIAB (Coordination of Indigenous Organizations of the Amazon Brazil) says there have been 667 deaths and 24,866 infections from Covid-19 by September 28, 2020; APIB (Articulation of Indigenous Peoples of Brazil) says 830 dead and 34,412 confirmed cases. FUNAI (Fundação Nacional do Índio) has been transformed by Bolsonaro government from an agency protecting Indians into two agencies given over to the agricultural interests. The violent incursions by miners and loggers has been increasing from 96 invasions in 2017, to 109 in 2018, to 256 in 2019. Some 24 leaders of Indigenous advocacy groups have been assassinated, including ten Indigenous leaders. Available at: https://www.sul21.com.br/ ultimas-noticias/geral/2020/09/ invasoes-em-terras-indigenas-aumentaram-130-em-2019/

6 On the shifts in historical struggles between the 1960s and 1990s over Yanomami land and health rights and over foreign research ethics as all three intersect with Brazilian national politics, see Fischer (2001). On historical shifts between the 1970s and 2000s in Amazonian and Colombian indigenous efforts at autonomy, self-governance, and cultural rights, see Fischer (2018).

7 On Xango, an Afro-Brazilian possession cult popular in Recife, see Halloy (2012).

8 Experientially, this is how I first received the film, first viewing it in Spring (2020), and immediately understanding it as a metaphor, among other things, for the disturbing politics surrounding the virus, that refused to accept public health guidance. 
Such protests spread across the globe, including a Black Lives Matter protest in Recife, northeast Brazil, in June 2020 (the hometown of directors Kleber Mendonça Filho and Juliano Dornelles), calling into further question Gilberto Freyre's (1933) effort to elevate Black culture and mobilize a multiracial or interracial ideology for Brazil $^{9}$ and a number of Indigenous Lives Matter protests as their lives became threatened by Covid-19 in addition to invasions of Indian lands by prospectors, loggers, and farmers. The protest in Recife came after the city witnessed the death of a black maid's son who fell from the ninth floor of an apartment building while being negligently "looked after" by the maid's white employer, while the worker was walking the dog. Gilberto Freyre, himself originally from Recife, was a student of Franz Boas at Columbia University and wrote a series of influential books codifying hopes for a multiracial Brazil that could avoid North America's binary racism. The Recife protest is one of many signs that this multiracial ideology with its 136 nuances of skin tone self-identity categories is being put under strain. ${ }^{10}$

The film Bacurau proved popular, selling 750,000 tickets despite the pandemic, and making back one and a half times its production costs so far (Rubenstein, 2020). It provides Brazilians (and others) with historically grounded images, as actor Silvero Pereira put it, of "the form of government or governance we have always had" (ibid.). The reception of the film among Brazil's leading reviewers reflected the polarization of society, some seeing it as a masterpiece, others as depraved or barbaric (Bloch, 2019; Escorel, 2019). It seems as if reality follows art, although as the film makes clear, the signs and cultural trappings are long-standing. For Brazilians, the film provides recognitions in cultural history back to Cinema Novo and Tropicália of the 1960s and earlier to the 1928 modernist Manifesto Antropofágico (cultural cannibalism, mixing genres and styles from around the world, metabolizing them into something distinctively Brazilian). At the same time, it incorporates 1970s American Westerns and Vietnam War films like Apocalypse Now (1979). Reviewers in the United States assimilated it to Hollywood genres, and the reviewer in Variety, Peter Debruge (2019), even went so far as to say "Bacurau is that rare movie that probably would have been better if it had been dumber, or at least less ambitious... Bacurau doesn't quite work in traditional genre-movie terms. Rather, it demands the extra labor of unpacking its densely multilayered subtext to appreciate".

That, of course, is a virtue, not a defect for a text of cultural politics about historical and structural features of race and authoritarianism in Brazil, different from, but similar to, those in the United States, and becoming more similar as the Mayor in the film and Presidents Jair Bolsonaro and Donald Trump mirror one another. Bolsonaro, after he tested positive for the virus, put a picture of himself on his Facebook page in early July 2020, reprinted in The New York Times, holding a pill of hydroxychloroquine, also recommended and taken (against doctors' advice) by Trump as one of a series of nonsensical, wishful or hallucinatory recommendations. Around the same time, a cartoon appeared in the American social media of Trump with a large piece of tape over his mouth, and Dr. Anthony Fauci saying, "I found the best way to save hundreds of thousands of lives".
9 Freyre famously asserted that "every Brazilian, even the light skinned fair haired one carries about him on his soul, when not on soul and body alike, the shadow or at least the birthmark of the aborigine or the negro, in our affections, our excessive mimicry, our Catholicism which so delights the senses, our music, our gait, our speech, our cradle songs, in everything that is a sincere expression of our lives, we almost all of us bear the mark of that influence". In its day it was an effort to promote black culture and protest against European and other Latin American efforts to justify racial separatism. Today, it is criticized by some as an assimilationist-miscegenous vision that erases the marks of slavery and demands for reparation.

10 In vernacular discourse on race and skin color, see Lilia Schwarcz's meditation on the 136 different skin color terms that Brazilians named themselves on the 1976 Pesquisa Nacional em Domicílios, changeable depending on "social situation, economic status, the day in question, and other contextualized perceptions" (Schwarcz, 2017, p. 183), and Simon Schwartzman's discussion based on earlier household surveys and censuses (Schwartzman, 1999). 


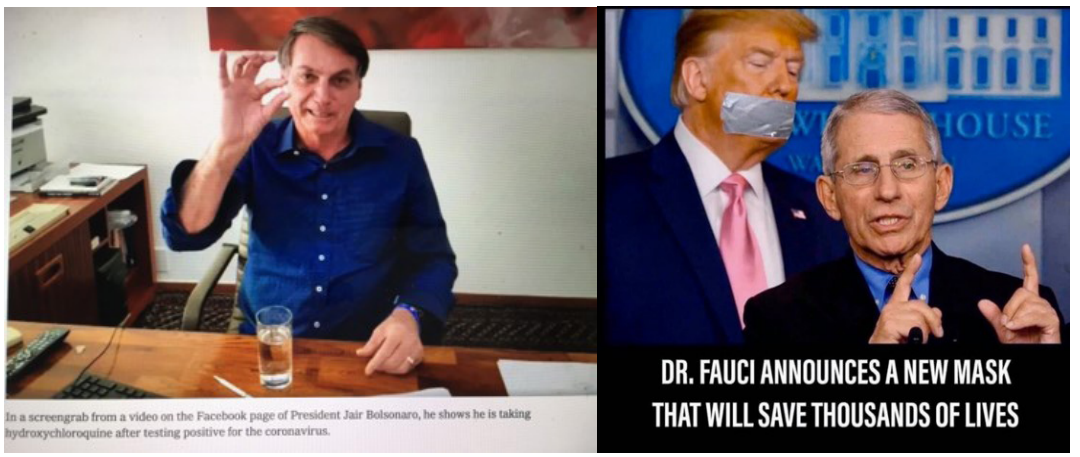

(In October 2020, Trump, too, and many of his White House employees, tested positive after an intense set of campaign events in which he and his supporters refused to wear face masks). Bolsonaro, Trump, and the Mayor (in the film) wage culture wars against education and the media (including film-making), promote extractive - and inequality - intensifying economies over public health, discount climate warming and the destruction of the Amazon, and dismiss Black and indigenous health and rights claims. Bolsonaro's pill looks like, but of course, is medically and compositionally different from the villagers' tiny psychotropic ball. The pill is a chemically and industrially produced immunosuppressive and anti-parasitic, the psychotropic ball is from natural plants to expand the mind to see what is important in life while undertaking stressful tasks (funeral, fighting invaders, administering punishment to evil-doers).

The film, after all, is a popular culture text, parodic, entertaining, and serious. Like any epic, street theater, or folk form it comes both locally tailored and globally transmittable. It operates triply: first, in ludic, Bakhtinian carnivalesque mode of counter-politics - almost a reinvention content-wise of the eighteenth century Bumba Meu Boi lower class festivals, which made (sometimes violent) fun of landowners and power-holders, and which continues to be performed (albeit as a bull-centered festival) in northern Brazil (where the film is set) ${ }^{11}$. Second, it operates as director Mendonça says, “for us, Bacurau is a microscopic re-enactment of the Vietnam war", a condensation of filmic representations of the American war in Vietnam. He says he drew on a change in representations of violence in American Westerns that began in 1972, which no longer portrayed Indians or the other as passive zombies (Mendonça, Lincoln Center, 2019). Thirdly, it operates, as Silvero put it, as a condensation, not of any particular government in Brazil, but of the "government that we have always had", the deep structure of violence, and the resistance through communal self-reliance and through the love that outcasts learn to accord one another and to use as a philosophy of life in overcoming grief and despair, so as to be able to live on with self-dignity.

The film continues in its reverberations for months and, today, even over a year after its release. In April 2020, implicitly countermanding Bolsonaro and Trump's belittling of precautionary measures to slow the spread of Covid-19, the cast of Bacurau appeared in a public service video, using a scene from the film, appearing without costumes or makeup and facing the camera, to directly appeal to the public to wear face masks, keep social distance, and stay home.
Images 1 and 2: Presidents Bolsonaro and Trump promote hydroxychloroquine

11 This slightly counter-intuitive suggestion comes from thinking about some of the references in the funeral dirge for Carmelita as well as some of the older features of the folk festival. I was first struck by the name Babau, a mythic animal, enacted by a man under a sheet representing a horse, and making sounds by vigorously clicking the jaws of a horse; by the theme of death and resurrection (of the bull; of Carmelita); by the character of a pregnant black woman (Carmelita as a mother to a wide diaspora of people); and by the many stock characters including a doctor or healer, a sacristan, prostitutes, a figure who hands out cachaça (or psychotropic balls in the film), the white landowner (or mayor), and a mix of Indigenous, Black, caboclos, vaqueros. I wonder if the sharp-toothed jaw in the desert as Acácio goes to get Lunga from the dam is a reference to this Babau. Interestingly Babau is also the name of an important Tupinamba Chief, whose Portuguese name is Rosivaldo Ferreira da Silva and who has been targeted for assassination by landowners in his attempt to help the Tupinamba get the state to demarcate the land promised to them, and which Bolsonaro's government has said claims to which will need to be (again) investigated, and who accuses the government, as do many Indigenous leaders, of using Covid-19 as part of their efforts to eradicate the Indigenous people. Sex, food, and violence are part of the fun of the Bumba, Meu Boi carnivalesque, as they are in the film. Processions of Bumba, Meu Boi often go to churches named after Saints, as the dirge invokes St. Nicolaus. A donkey figures in the Bumba, $M e u B o i$, and in the film an old medieval humiliating tradition of putting someone on a donkey backwards and banishing them as is done to the Mayor. 


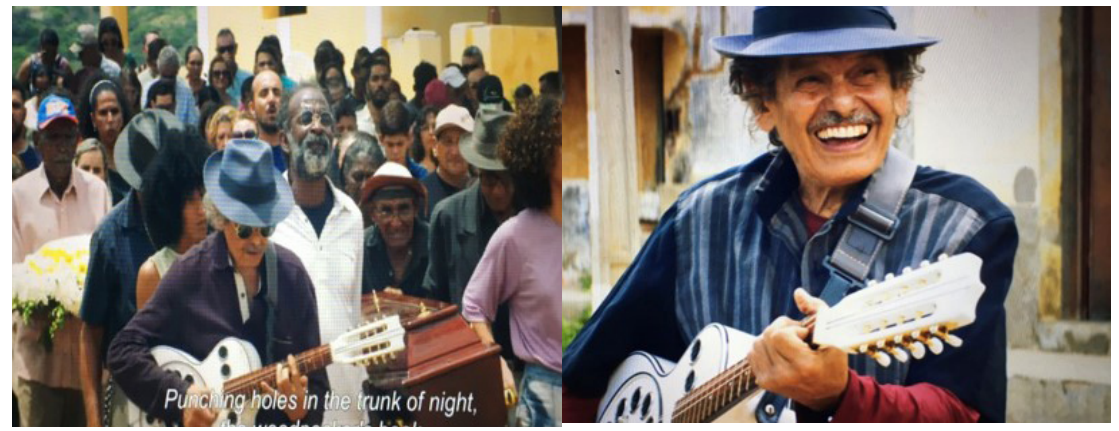

Month after month there were funerals of hundreds of Indigenous people killed by Covid-19, including a number of well-known Indigenous chiefs whose obituaries made international news, including Bep'kororoti or Paulinho Paiakan, the 68-year-old Kayapo leader of the fight in 1988 against hydroelectric dams on the Xingu River, and three years earlier the remarkable expulsion of 5,000 miners by leading a hundred war-painted warriors pretending to be many thousands; 71-year-old Aritana Yawalapiti, one of the leaders who helped create the Xingu Indigenous reservation in 1961, a 6,5 million-acre home to 7,000 people from 16 tribes; and 53-year-old Messias Martins Moreira Kokama, the founder of the Tribes Parks housing complex in the city of Manaus with paved streets, electricity, and basic health services for 700 families (2,500 people) from 35 different Amazonian tribes speaking 14 languages. For him, an exception was made to Manaus' city ordinance - allowing only two people at a funeral during the COVID-19 crisis - so that people could gather around his wood coffin wrapped in cling film in the unfinished school he was building and dance and sing as he had requested, including singing the national anthem in Tikuna. People wore face masks emblazoned "Indigenous Lives Matter (Vidas Indigenas Importam)”. (Name the Names! the slogan of Black Lives Matter applies also to Indigenous lives). Among the Indigenous peoples, only Xingu Park has been able to block all outsiders and prevent any infections as of early June 2020.

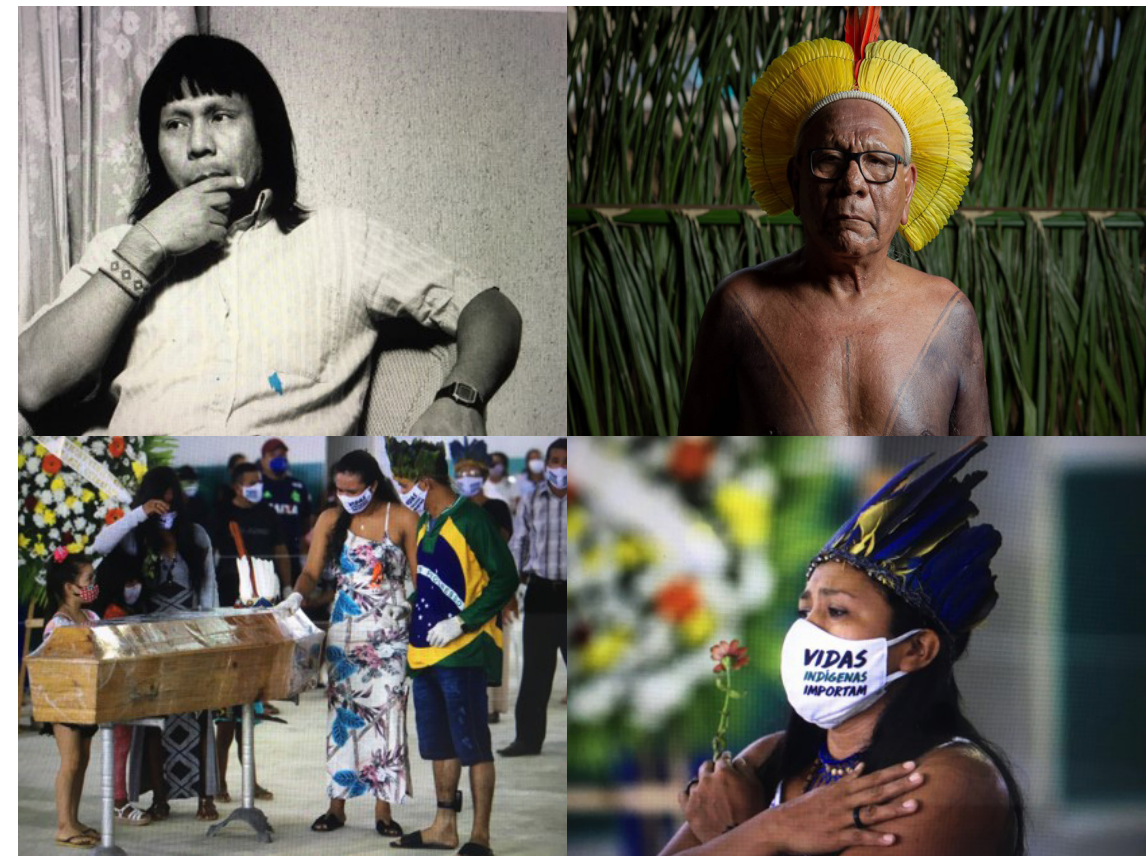

Images 3 and 4: Funeral Procession for Carmelita

There is a striking mash-up of Bacurau together with Todd Philips' film The Joker (2019), which also turns on the intuition that Bacurau is or could be carnivalesque, particularly the scenes with the Joker in clown face laughing at the mayhem in the streets. Available at: https:// www.youtube.com/watch?$v=g D S T 2 H N C D d w$, posted by Normose@gmail.com
Images 5 and 6: In memoriam: Paulinho Paiakan (Yanomami)(death in 2020 by Sars-CoV-2 - Covid-19)
Images 7 and 8: Casket of Chief Messias Kokama, 14 May 2020, died of Covid-19; Indigenous Lives Matter face masks 
Bacurau may have a continuing life also as a meme, much like the title of the 1997 American film Wag the Dog. Silvero Pereira, in an interview, turned the title into a verb: "If necessary, we will bacurize not to lose the rights that we have achieved" (Rubenstein, 2020). Brazilian politics continues to enact what the film describes with the assassination of Rio city councilor Marielle Franco on 14 March 2018 and arrest in November 2019 of two suspects with alleged ties to President Jair Bolsonaro and his sons, and the subsequent resignation of Justice Minister Sergio Moro on 24 April 2020 over Bolsonaro's threat to remove the head of Brazil's federal police and Rio de Janeiro's superintendent of police, along with Bolsonaro's mishandling of the pandemic (Londono, 2019; Phillips, 2018, 2020), not unlike Trump's interference with and firings of prosecutors within the U.S. Department of Justice to protect his cronies and allies ${ }^{12}$. Sonia Braga, who stars in Bacurau, already on August 25, 2019, was shown protesting the Amazon wildfires set by invading prospectors and migrant farmers with government (and Bolsonaro's explicit) encouragement to clear the land, her hands painted red for the blood of Indigenous peoples lost or being put at risk.

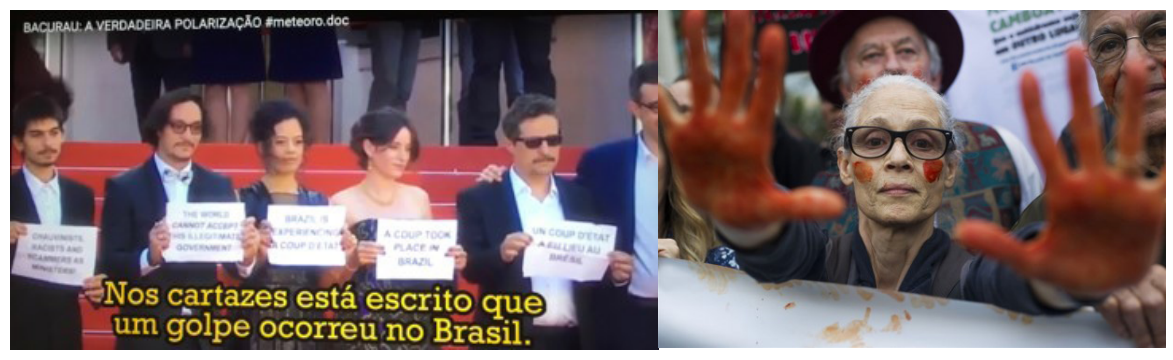

\section{Reading the Film and its Viral Social Drama in the World}

Filmmaking is a mode of hallucinatory daydream, picking up hidden alerts in the everyday, turning them into reminders, warnings, and at times fire alarms. Cultural productions, in this way, are social dramas. The "film itself", whatever that might mean since it is always a screen or stimulant for interpretations, often becomes almost a secondary artifact and amplifier for the social drama and reception. The molten form of film - in both its making and its reception - draws attention to fragments of the world, mutates from ideas to images and sounds, and then enters people's thinking as stimulant and hallucinogen. This is intensified by the use of a series of only second long flashes of images foreshadowing or reminding of things to come or references to remember. The molten form of film becomes involved in on-going social arguments and struggles. It is no wonder that authoritarian governments fear film's power. The moving molten flow of filmic judgment burns to the touch or to the effort to arrest its effects or subordinate them into an official story.

A fascinating feature of films, with generative power in the imagination, is often the double consciousness or delicate slippage between on the one hand trying to identify the realism (location, linguistic accents, behavioral gestures, hairstyle and skin tone etc.) and on the other hand playing with the presented
Images 9 and 10: Cannes 2016; August 2019, Sonia Braga

12 Marielle Franco, a 38-year-old black bi-sexual Rio city councilor, born in the favelas, was assassinated on 14 March 2018, a day after she spoke out on Twitter against police violence in Rio and an hour and a half after attending a round-table on "Young Black Women Moving [Power] Structures". A month earlier she had attacked President Temer's federal intervention in Rio putting the army in charge of policing, and she served on the council to try to oversee that intervention. Two former police officers with ties to President Bolsonaro's family have been arrested; the bullets used have been identified as from a batch bought by the federal police. The Justice Minister, Sergio Moro, resigned over the removal of the federal police chief by Bolsonaro, accusing him of interference in the investigation and prosecution. Moro was also critical of Bolsonaro's mishandling of the pandemic. On another front, on 14 April 2020, the Federal Government announced to black quilombolas communities in Maranhão 
tokens in a more conceptual filmic or "symbolic" logic. For instance, for some, to call the village in Bacurau a quilombo feels wrong or incorrect. A quilombo is a refuge village of descendants of escaped slaves (maroons in the Caribbean). An interviewer asks the director Kleber Mendonça Filho if the village is a quilombo mixed "with indigenous, white, trans and other members... a black community with a history of resistance". Mendonça acknowledges the idea, but says, he is "not using that word" (Bittencourt, 2019). ${ }^{13}$ In Bacurau, as in his films about Recife, Mendonça revels in the texture of ethnic and cultural diversity brought to places by their characters' different backgrounds (Sbrizzi, 2012). He dismisses films that he calls "ethnographic", by which he means ones that turn Brazilians into "simple" people (Bittencourt, op. cit.).

The village, Bacurau, by contrast, allegedly located in the outback of "Pernambuco", although shot in neighboring Rio Grande do Norte in the village of Burra, is indeed an iconic site of separation and resistance as Bittencourt suggests, just perhaps not exactly a quilombo. The film, after all, is fiction, and yet, certain features anchor the film in the reality of the Northeast: the landscape, the form of the village, and certain of the characters such as the young woman Teresa whom we meet riding shotgun in a water tanker careening down a road in the typical dry caatinga landscape (Tupi: white vegetation of pale withered trees and cacti). The slippage and double consciousness between staging the real and the workings of its symbolic logic are crucial to the addictive appeal of the film (as also to theater, novels, and paintings).

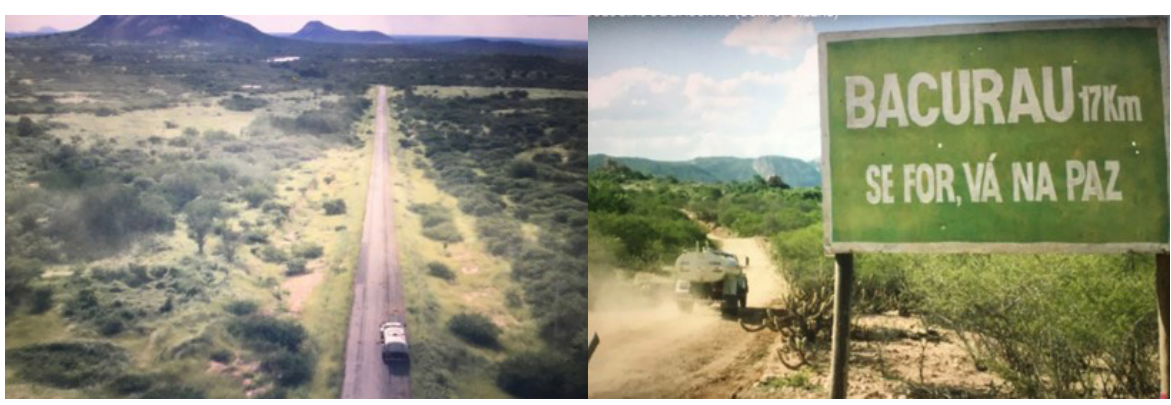

Symbols can accrue meanings as they travel to new contexts and audiences. But this does not mean that they are merely subjective, arbitrary or any interpretation goes: the boundaries of interpretative validity may be fluid and shifting, but it is precisely those shifts of context that are ethnographically and historically significant, whether they are in viewers' heads, or in the borrowed tropes and genres used inventively by cultural producers, including filmmakers such as Mendonça Filho.

The film is entertaining and mythic, set in the Pernambuco outback (sertão), and populated with finely etched, individualist, oddball characters as well as pop culture genres and plots. Can one read it for "alerts" or "fire alarms" in the everyday dynamics that surround us, a bit exaggerated, even caricatured, enough to be funny, and yet underneath tapping into deeper unsolvable paradoxes and dilemmas? Can one read it, not to reduce it to its director's cultural politics, but on the contrary, for the cultural politics in its diegetic registers and the way its that it would begin expansion of the BR135 highway in May, in the midst of the pandemic. They circulated a two-minute video accusing the government of attempting genocide: https:// drive.google.com/file/d/1F6rG5bwt3XiJARAKroRZH2MhNj-

\section{dPrV7t/ view}

13 But now see the protest video by self-identified black quilombolas of Maranhão accusing the government of genocide in beginning work on widening highway BR135, which will destroy homes, gardens, and forests and create genocidal conditions. And more generally, on the use of quilombo for a political movement to secure rights guaranteed under the 1988 Constitution, now being threatened, see Bispo dos Santos $(2015,2020)$, Nascimento (2002), Neiburg and Ribeiro (2002), Moura Fagundes (2020). Available at: https://drive. google.com/file/d/ 1F6rG5bwt3XiJARAKroRZH2MhNjdPrV7t/ view

Images 11 and 12: Water tanker in caatinga landscape on the way to Bacurau 
divided reception further enacts that politics on a different stage? Kleber Mendonça Filho notes that both his previous films Neighboring Sounds and Aquarius, about changing middle-class neighborhoods in Recife, use mundane observations of everyday life, slightly heightened by the way shots are set up, or by or editing, to add a sense of menace or paranoia, or a slightly surreal twist, to make them interesting and fun. Alerts, or "fire alarms", are the terms in which Walter Benjamin, now already long ago, wrote of train wrecks, floods, and warfare as "slow disasters" ${ }^{14}$ which first accrue their causations unnoticed, suddenly fissure along human-made social inequalities, disrupting the flow of consciousness, and compose history as warnings against uncritical techno-optimism or any form of political or economic triumphalism and closure. None of these disasters of which he wrote (except perhaps the Lisbon earthquake) were natural, nor were they pure events that could not have been foreseen albeit only retrospectively - hence the temporality, paradox, and mystery even though they occur often as repetitions and not singular events as they appear at the time. Problems of materialist greed, individualist desires for independence, collective protection, or aspirations for transcendent harmony with the earth which shape these events and their interpretations - these are the matrix, or problem fields, of myth, ritual, and parable, that Bacurau draws upon.

But there is also an additional story of struggle between state authorities and culture producers, one that, as in so many cases, enacts some of the very readings that the state and cultural conservatives wish to deny.

The film, Bacurau, shared the 2019 Cannes Film Festival Jury Award together with Mali-born, French director Ladj Ly's film Les Miserables, about policing in a Parisian banlieue where three weeks of rioting occurred in 2005. Despite the Jury Award, Bacurau reignited a dispute with the Brazilian government of President Jair Bolsonaro. Soon after his election, Bolsonaro had abolished the Ministry of Culture warning about "cultural marxism", cut funding for the film and television industry, and during the production of Bacurau demanded that director Kleber Mendonça Filho return half a million dollars of the funding for his 2012 debut film Neighboring Sounds. In 2016 at Cannes, prior to showing his film Aquarius, Mendonça Filho and his cast carried onto the red carpet paper signs which they took from their pockets reading, "Stop the coup in Brazil", "We will resist," and "Brazil is not a democracy anymore". It was, they thought, just an ordinary protest against the impeachment and removal of President Dilma Rousseff ${ }^{15}$. That removal would lead through the competition for her successor, eventually to the election, from the populist right, of Bolsonaro, in an unnervingly parallel to the earlier election of Donald Trump in the United States, with similarly an enduring and unshakeable roughly thirty percent of popular support. There was payback for the protest. Aquarius was given a rare, punitive plus 18 rating (reduced to 16, after critics protested), and although it went on to gross $\$ 1.2$ million at the box office, Brazil refused to submit it as its foreign film Oscar candidate, causing a public airing of disputes within the selection committee, and the withdrawal of other films for consideration by their makers. And a few months later, during
14 A term being used by disaster historian Scott Knowles for the slow unfolding of disasters, some of which are anticipated but allowed still to unspool, others are only recognized retrospectively as patterns that might have been apprehended if one had the knowledge or schooling or antennae to pay attention.

15 Rousseff was supposed to be a four-year placeholder for President Luiz Inácio Lula da Silva, who could not run for a third successive term. Instead, she ran for a second term herself. Amidst widespread corruption scandals, she was found to have violated specifically legal budgetary rules, by attempting to roll over hidden deficits. Lula was imprisoned on charges he is still fighting and was ineligible to compete in the next elections, and so Fernando Haddad, a former mayor of São Paulo, was named Workers' Party candidate in the contest against Bolsonaro. 
the production of Bacurau, Bolsonaro's government demanded the return of the money for Neighboring Sounds (Kohn, 2019; Nordine, 2016; Dodman, 2016).

Aquarius, starring Sonia Braga, like Barucau, was not overtly political ${ }^{16}$ and had been made before the impeachment of Dilma Rousseff, although conservatives urged the film be boycotted as ridiculing Brazil and its developmentalist drive, and in turn supporters of the film staged noisy demonstrations at screenings, against interim President Michel Temer (“Temer out!”) who succeeded Rousseff and began many of the policies continued by Bolsonaro. Similarly, Bacurau's filming began before the October election of Bolsonaro, and its release was in September 2019 before the outbreak of the global Covid-19 pandemic in December 2019. And yet. Asked in Cannes in 2016 by The Guardian if Aquarius was intended to comment on the country's push for capitalist progress, Mendonça said: "good films or books pick up on things in society, or in a country, but it is too early to say if this film does that before the film actually screens and people react to it... Only then will I know. I am curious myself" (Shoard, 2016). As many artists often say, they are not sure what the art means; sometimes art catches things not yet manifest, but already in the air; sometimes it does not. In 2019 he was blunter: although the idea for Bacurau began in a discussion with Julian Dornelles (the co-director and former production designer for Mendonça) in 2009, and was in slow development for almost a decade, the shooting was in 2018 both before and after the October election of Bolsonaro, and more importantly, says Mendonça, "the extremes of Bacurau were fueled by Bolsonaro's election" (Coyle, 2019). "It was almost like reality was catching up with the script. When that happened... we went over the top" (ibid.; also, at the Cannes Press Conference, 2019). Rather than staging another protest on the red carpet, "we used the movie as our weapon," said actor Thomas Aquino, who plays Acácio, the former gang member (then called Pacote) who returns to the village and becomes its main mature male defender. "This is our answer. This is how we protest" (ibid., and again also at the Cannes Press Conference, 2019). The final credits in the film note, in a fairly direct criticism of the Bolsonaro government, that the film generated eight hundred jobs, and that film is both identity and industry, neither only industry with financial imperatives nor lapdog to ideology on whatever side (prevented by the very polyvocality of interpretation and reception).

There are two key threads of the protest, one the destruction of cultural institutions ${ }^{17}$, the other the "ethnographic" stereotyping of the Northeast as "simple people”, accepting of poverty, underdevelopment and exploitation by landowners, especially in films by "southern" Brazilians (i.e. south of Bahia). Co-director Dornelles says in an interview, "the Northeast is where maids come from and where Kleber and I are from. We wanted an adventure where we are the heroes" (ibid). Actor Silvero Pereira, who plays Lunga, and is a well-known transvestite or drag actor, ${ }^{18}$ is quoted in Brazil Wire as saying, "I come from a very silenced culture... characters I saw on public television, in cinema, in music. There are few that I look at and can say that they are similar to me. Today, I have the opportunity to do it differently. This is very important, as a political act to let people know that our rights have been won and that we cannot back down" (emphasis added; Hunt, 2019) ${ }^{19}$.
16 Starring Sonia Braga as an elderly writer who challenges the son of the owner of a corrupt construction cartel in Recife, it was made in 2016 in the aftermath of the 2013 demonstrations of students and intellectuals who aligned with a poor neighborhood in Recife against a plan to replace the neighborhood with high rise buildings.

17 "While Bacurau was premiering Wednesday night in Cannes, tens of thousands of students and teachers protested in Brazilian streets over steep budget cuts to education announced by Bolsonaro. The filmmakers said they stood in solidarity with those protesters" (Coyle, 2019). At the Cannes Press Conference, asked about it, Mendonça said: "I am incredibly proud, and prouder of the protest we did 2016 at the world premiere of Aquarius"; not only do "we fully support the protests that took place in Brazil yesterday", but to have Bacurau "screened at a time when there was this whole idea of destructing culture in Brazil, the arts in general, and I think it's so fucking amazing to have a film at the Cannes Film Festival right at the time when they are actually trying to hide everything we do".

18 In an interview, he acknowledges that he talked the directors out of writing him as a transgender character, that he does not identify as transgender, and prefers not working with an identified gender. He is part of a theater collective in Fortaleza called As Transvestidas. Drag, he says, "doesn't have anything to do with sexual identity... do you have to be LGBT to be a drag queen? No". He has hopes for a sequel in which more of the backstory of this character can be presented (Rubinstein, 2020). At the Cannes Press Conference in 2019, however, he explicitly says the character is transgender and that in Brazil today there is a need to explicitly talk about transgender and the hundreds of murders against the LGBT community. He shows up at that Press Conference 
There is a third thread not yet evident until the pandemic breaks over Brazil, but then unfolding as a piece of the same set of relations: Bolsonaro's (and Trump's) privileging of the economy over public health, and like the Mayor in the film, pretending to be the patron and protector of the working poor.

Bacurau is a name with many meanings of course. In English it is a Nighthawk, a member of the nightjar family, that is active especially at twilight. At rest, on a twig with wings folded, it seems small and camouflaged, with a small beak. When it flies at dusk, its beak extends wide, and it scoops up insects. For anthropologists, trained by Lévi-Strauss to think in terms of the classificatory systems of indigenous South American cosmologies, it is thus a liminal creature between day and night, this world and the unseen world, sky and earth, albeit not quite a hawk or eagle (it is not a raptor and flies lower). In colloquial English, nighthawk is a term for someone who has been up all night, often drinking and hallucinatory, and indeed there is a scene of a young woman who comes to the doctor complaining of symptoms which the doctor immediately diagnoses: you are hungover, go drink lots of water, vomit, sleep. In the slang of the film-maker's hometown of Recife, bacurau is also the "last bus" at night.

Nighthawk Interactive is the name of a prominent video action game-maker. The film itself might be just one of their action games; and it invokes the "industrial" music "The Night" by John Carpenter. The fancy motorcycles that the two Brazilians "from the south" "from Rio" says the woman later flippantly, "from Sao Paolo" says the man) tool around on might be Honda Nighthawk 750s, just as the airborne drone with its video-enabled surveillance camera might be a slyly reference to Lockheed Nighthawk attack helicopters. In high camp retro style, the surveillance drone is shaped like a flying saucer and is light enough to be held in one's hands. Like the running visual joke of failing to find the village Bacurau through Google or satellite mapping (when the cell phone signal is cut off by the shooters; although there is a geodetic-geographic marker in the center of the village, as well as an old Massachusetts-made cotton gin). These tokens are reminders to pay attention to the constructed realities of power structures and the ability of people to resist through solidarity. The inability to find Bacurau on the map is also a comment on high-level government plans and maps that ignore (do not see the specificities or contexts of) local villages.

The film Bacurau is set in the sertão, in a village whose water is being cut off by an extortionist mayor of the region and near-by town (and who, to reinforce the varieties of extortion, openly takes village girls for his sexual pleasure). The village, however, is populated with a rich mix of mysteriously compelling characters with, it will turn out, potent powers of their own, albeit weapons of the weak. The threat to the village is condensed in a single image, a casket over which water flows, much like Walter Benjamin's notion of a "peculiar condition in which history appears to be concentrated in a single focal point," or in an eyeblink ( $A u$ genblick) of insight, or the flashing up (Aufblitzen) of clear vision. Water and caskets recur throughout the film. Water rights are contested politics in northeastern Brazil. Also, in other places in Latin America, where multinational corporations at- dressed as a beautifully made-up woman. In the movie, his character shape-shifts from a T-shirt and shorts-wearing tough male to a long-haired bare-chested and necklace and bangles wearing warrior that has a little old lady call out "Some outfit, kid!".

19 In the interview with Rubenstein, he identifies the evils in the film as the political system, the macho politics of the coronéis (landowners), and the taking away of rights that have been fought for and achieved by the LGBTQIA+ community. "If necessary, we will 'bacurize' to not lose the rights that we have achieved. Black people, LGBT people, women, Indians, the poor, and Northeasterners are the majority in this country, and our nation has an obligation to build historic reparations with these communities". But again "this aspect doesn't interest the members of the community who you are in a relationship with. What is important is having respect. So you have a transwoman who's married to two men;... you have a doctor. . and she is in a homosexual relationship" (Rubenstein, 2020). 
tempt to seduce villagers with promises of building them water infrastructures, but then forcing them to pay for the water (Ballestero, 2019). Critical, too, is access to electricity and light for all, which President Lula had inaugurated (Luz Para Todos) along with his Bolsa Familia (family support program); and cell service ${ }^{20}$. The dense image of water flowing over the casket (without water, death) is also one of washing the dead and purification, as is the folding of white handkerchiefs by women as Teresa brings in the red suitcase. These handkerchiefs will be waived by the mourners in the funeral procession like a flock of birds.

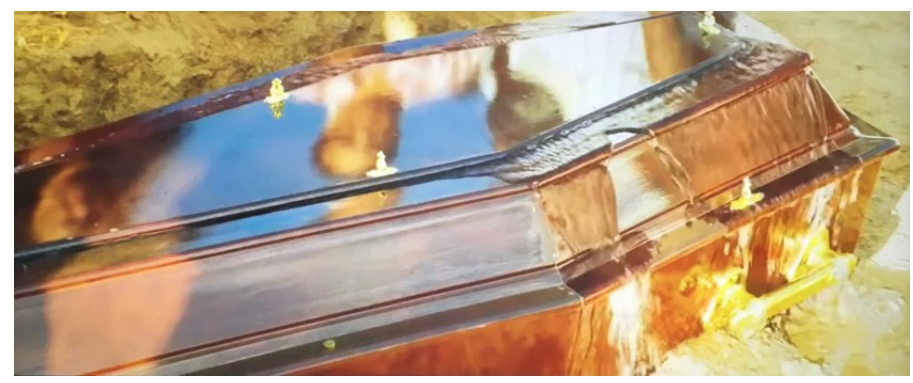

\section{Plot, Video Game, Hybrid Cultural Warfare}

Caskets are littered along the road. A transport truck spilling caskets has hit a motorcycle, leaving the cyclist dead by the road. Caskets lying on the road are hit and smashed by the water tanker which has been weaving along the deserted road trying to avoid potholes, defiantly bringing water to the village.

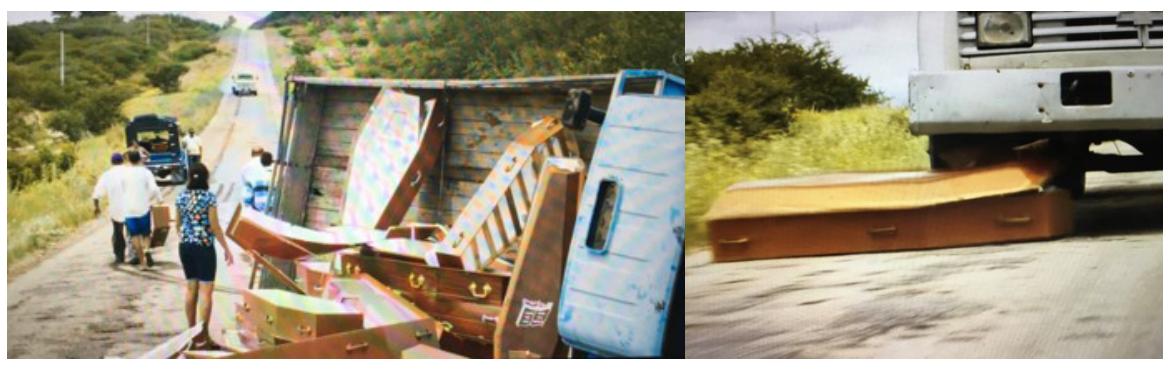

The impact jolts the sleeping young woman Teresa in a white lab coat riding shotgun in the water tanker. Asked by the driver why she wears a lab coat in the heat, she says "for protection", at which he nods and says, "makes sense". As they pass the wreckage, they hear a man say to the trucker, "we will take two [of the caskets]" (a windfall to be seized), and a woman talks on a cell-phone (satellite service everywhere). They pass the ruins of a school with the faded name, Escolar Municipal Silvino Addhias Bezerra, a fragment of old state services ${ }^{21}$.

As the tanker stops on a hill overlooking the dam, which should supply the village water but which has been blocked by the mayor and his paid gunmen, a "wanted" image comes over the monitor in the cab, promising reward and anonymity for turning in the "bandit" Lunga. The driver explains that Lunga had tried to get the water released, but was unable to overcome the gun battle that ensued ${ }^{22}$. Teresa, the young woman in the white coat, says, "Don't count on me to deliver
20 Begun in 2003, Luz Para Todos in its first 15 years is said to have connected 16 million people, including 35 thousand indigenous families, 29 thousand quilombola families, and 14 thousand schools in rural areas, with a goal of adding another 2 million by 2022. Available at: https://pt.org.br/luz-para-todos-completa-15-anos-atendendo-16-milhoes-de-pessoas/ and https://www.redebrasilatual. com.br/cidadania/2018/11/ luz-para-todos-15-anos-do-programa-que-levou-eletricidade-aos-rincoes-do-brasil/.

Image 13: Death \& Water (Carmelita's coffin)

Images 14 and 15: Coffins and death on the road

21 Silvino Addhias Bezerra (1887-1969) was a public prosecutor, judge, state attorney general, founder of the Association of Assistance to Psychopaths (which created the Hospital Colônia), a founding member of the Rio Norte Historical and Geographical Institute, and a founder of schools. Available at: https:// centenario.ifrn.edu.br/ex-diretores/silvino-bezerra-neto.

22 One reviewer identifies the dam as part of the Rio São Francisco, a large-scale irrigation project first planned during the time of Emperor Dom Pedro II, but taken up as a major 
Lunga [to the authorities]". The driver agrees. A warning shot from the dam moves them on their way (on a later trip into the village, it arrives with gunshot holes leaking water). Teresa tells the driver she is bringing protection. She now is referring not to the white coat for her own protection, but to the medicines she is bringing to the village. She dismounts with a red suitcase in tow, waves at Domingas, the woman village doctor (Sonia Braga), who looks out sourly from a window, chugs a drink, and slams the shutter. As she walks on, Damiano, a middle-aged man, steps up and pops a small fibrous ball or seed (a hallucinogen) first into his own mouth, and then one into hers which she accepts with a nod. He watches her carefully until she swallows; she then laughs, kisses his cheek, and walks on as he smiles. She brings the suitcase into a yard where people are gathered and into the house, handed over the heads of the gathering to deliver the vaccines to the doctor: polio, triple DPT [diphtheria, pertussis, tetanus], and an anti-phallic or snake-bite serum. All these drugs - hallucinogen, drink, and serum - portend a coming drama beyond the funeral of Carmelita, Teresa's grandmother and Domingas' lover, for which Teresa has returned to the village.

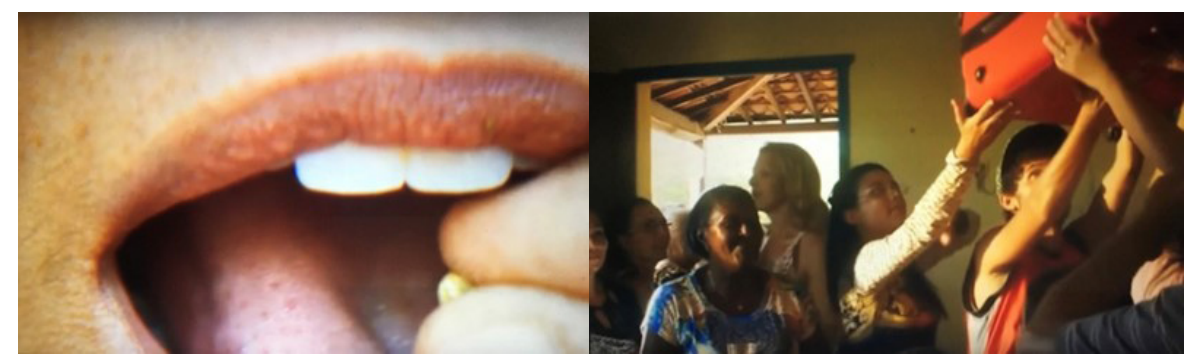

On this iconic outback stage, a high-tech safari hunt or video game (with drones, Bluetooth earpieces, cyber-attacks on electricity and cell phone transmission, and even tiny battery charged translation devices) is superimposed in which white Americans and Brazilians (the couple from the South), led by a hard-faced German-American are let loose to shoot villagers, accruing points for each kill. The gamers have been given access and protection by the Mayor in a deal brokered by the young motorcyclists, who identify themselves to the villagers as "from the south", and with the Americans as "fellow whites" (who however see them as Latino). When the gamers shoot the two motorcyclists from the south, they find a photo identification card in the pocket of the young man, which reads "Judicial Power, Regional Court of the 6th district, Federal Judge Advisor, Mauricio Gomes Carneiro" - a hint of a Brazilian police sting that goes awry? Or hybrid warfare that goes awry (Leirner, 2020)? Another layer of potential plotting to speculate with that the film does not follow up? Or is it another indication of the ineffective and corruptible government (after all, the two Brazilians have just killed two of the villagers), underscoring the need of the villagers to rely on themselves for self-defense? A burned-out and shot up old police car is later found by the gamers, who are puzzled having been told by the now-dead young man from São Paulo that there are no police in this area.

There is a museum in the village, which intruders such as the couple from the South and later others among the shooters, are asked if they have come to project by the government of Pernambuco native, former President Lula da Silva (Hunt, 2019). This reviewer would thus make it again symbolic of the Bolsonaro government blocking off and reversing the gains for the poor instituted by Lula. In September 2020, in a cynical counter move, Bolsonaro went to the irrigation project and claimed its inauguration as his government's contribution, though nothing more has been done to make it a reality, and it is a project which would take 10-15 years to accomplish. It is another repetition of governments promising to bring water to the arid north but promises always falling victim to national politics in the south.

Images 16 and 17: Psychotropic; Red suitcase with vaccines 
visit, and who always, uncomprehendingly, demur. It seems like an internal joke in the film, an icon of a history of resistance that persists and cannot be stilled, a materialization of memories of the past oppressions that flash up in a moment of peril ("im Augenblick einer Gefahr aufblitz"23 [Benjamin GS I -2, p. 697; Benjamin, 1940; Marramao, 2008]). An observation on the title of the film comes when the Southerners ride into town on their flashy motorcycles and in garish outfits, and the woman of the pair asks the woman shopkeeper what Bacurau people are called. The shopkeeper's little boy replies, "gente!" (human beings). Score 1. Gente, as in we are your equals not exotics; but also, gente from everywhere, not necessarily all originally from here but here is home and refuge. To which the motorcyclist asks what the name means. The shopkeeper responds: "a bird". The Southern woman, not able to leave good enough alone, parries: "a small one?" Shopkeeper: "no, a large one". Southern woman: "Is it extinct?" Shopkeeper slyly: "not here, it comes out at night and is a hunter". Score 2. In the climax battle of the film, one of the shooters goes into the museum to search for hiding villagers and discovers a wall of museum labels for a Mauser (1908), a Winchester 44 rifle (1873) and a Colt-38. The weapons are gone, and he realizes, too late, the villagers are armed and dangerous. The villagers shoot and kill the intruders who, had they visited the museum earlier, might have learned of the years and centuries of determined resistance and survival skills.

The village counterpoint to the steely-eyed German-American leader of the shooters (multiply marked as "other") is the music video styled punk and drag dressed Lunga in eyeliner and glitter. Born in the village, he is an erstwhile Recife gang member, holed up in a guard tower on top of an abandoned concrete dam. But when his cousins are killed by the shooters, he joins the villagers to lead their defense. In a brilliant fury of rage and grief, he cuts off the heads of the shooters the villagers have killed, a scene complete with carrying out the heads by the hair and setting them up next to one another on the door stoop of the Museum.

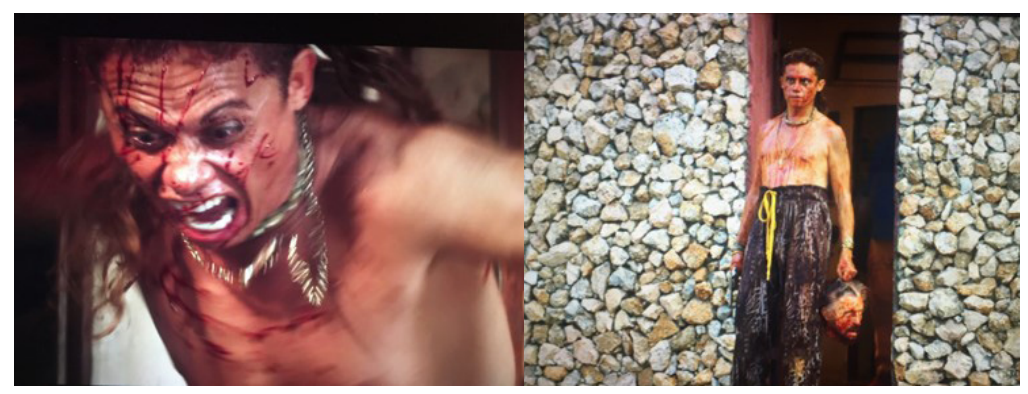

When the villagers clean up the splattered blood inside the museum, they leave one blood hand imprint on the wall (like Sonia Braga's red hands in the August 2019 protest) as a reminder of yet another successful defense of the village and of constant vigilance. In the final scene when the villagers come to deal justice to the Mayor and the head shooter, they are all given the small fibrous balls of hallucinogen (perhaps ayahuasca or something like it) to bolster insight, determination, and courage. The ball or seed is distributed by Damiano, who had put one in the mouth of Teresa when she first arrived with the red suitcase at the
23 "Flashing up in a moment of peril".

Images 18 and 19: Grief -> avenging rage 
beginning of the film and is later shown nude tending to his plants, and who, along with his also nude wife - from inside their farmhouse without coming out to take aim (with hallucinogenic powers of seeing or sensing through walls) - had shot and killed a pair (male and female) of shooters trying to sneak upon them. A long-held shot of cacti in the rain is montaged to that scene, so it is ambiguous if the hallucinogens come from the plants (cultivated) or desert cacti (nature) or a mixture of both, just as the man appears in the film both nude and clothed. ${ }^{24} \mathrm{He}$ says enigmatically about Lunga, acknowledging a critical trickster moral balance: "The man is worth more for the evil than for the good he can do", presumably that it takes evil to fight off evil, that he is a last resort for the village though, like the folk hero Lampião, not a good citizen in more normal times.

The severed heads allude to the story and motifs of Lampião, whose gang members' severed heads are in a picture in the Bacurau Historical Museum awaiting their revenge or repetition at the hands of Lunga. Mendonça at Lincoln Center said that Lampião here is "probably in his seventh-generation development into being a new kind of Lampião", but "in our minds, he probably spent some time in a state prison or a federal prison in Brazil" where frequently there are prison riots and then things get really savage and people just kill each other and cut their heads off and throw the heads over the [wall]".

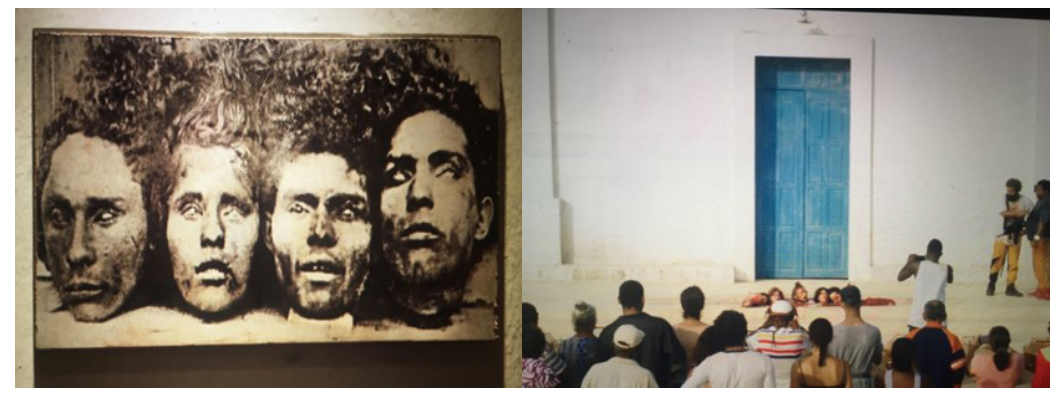

Apologizing, he goes on, "there are even videos made with telephones of inmates playing football with heads". His co-director, Juliano Dornelles, notes, and he concurs, that many of these prisoners are minors, under seventeen, not unlike the gang members that Lunga and Pacote were. And then with respect to violence, again he notes that both Brazil and the U.S. are amazing, beautiful countries, but they are also violent, and it is important to address that, as well as the violence that resides under facades of civility, law and order more generally in human societies.

The villagers use a variety of ritual forms, including a slow capoeira fightdance (done to the industrial sound of John Carpenter's The Night ${ }^{25}$ and visions of ghosts of the departed at a funeral) before mobilizing for the coming fight to defend against the shooters; there are hallucinogens and devil's masks, and warning music - a grinning old balladeer, playing an iconic Del Vecchio Dinamico Resonator guitar, senses the evil in the alien young Brazilian couple from the south and uses a distinctive Pernambuco song genre to taunt them ${ }^{26}$. If the Mayor has tried to buy the villagers off with donations of books for the library (poured en masse from a dump truck), food (with long expired dates) and medicine (mood pacifiers), the locals counter with the local ayahuasca medicine of insight and
24 Ayahuasca is a brew of psychedelic drug DMT and MAO inhibiting harmala alkaloids, which are necessary to make the DMT orally active.

Images 20 and 21: Severed heads, past \& present

25 The capoeira scene was not originally in the screenplay, but the actors began to dance it spontaneously on the set, so it was filmed. Mendonça Filho tells Film Comment: "I had the idea that perhaps if we joined the capoeira with just the sounds of feet and hands beating the rhythm, and then the music from [John Carpenter's] Night we would really have something. You hear the capoeira go on, but it is being drowned out by industrial sound". And Dornelles adds: "That moment - the industrial sound invading the scene - symbolizes the way that the place itself is being invaded by outsiders". Mendonça Filho gives a further nod to Carpenter by naming the village school after him.

26 "Do you know, sir / anything about the water tanker? / It came in full of bullet holes/ Good looking guy/ He's gonna catch the queer eye/ Just like a movie star / His pride swells, his balls grow apart/ Make the most of it now dude/ Old age sneaks up on you/ Check out the pretty 
clarity of collective defense.

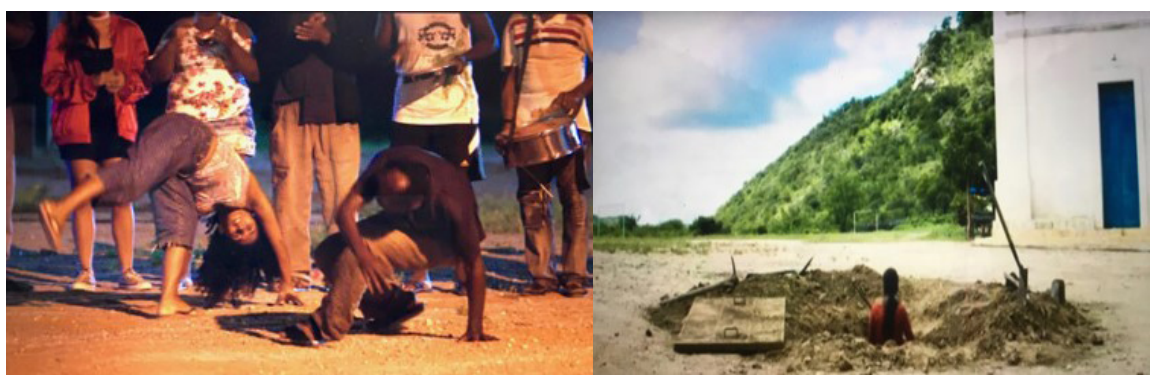

Thus, American imperialism and racial hierarchies within Brazil as well as transnationally are satirized in the conceit of a high-tech safari hunt or video game in which whites (Brazilians and foreigners) are free to shoot third world others (or more generally, the rich and powerful play their war games and development projects without concern for the lives of ordinary people). I am reminded of the San Antonio, Texas, Internet hunting, or remote-controlled hunting website Live-Shot. com, which allowed people to shoot game animals with a click of a mouse for a fee of $\$ 1,500$. Once it got publicity it was quickly outlawed in Texas and thirty-eight other states ${ }^{27}$. The founder claimed it was to allow the disabled to experience the thrill of hunting. The fictional safari in the film similarly sells the thrill of the hunt, emotionally detached from engagement with locals as other than targets, and shows the shooters as both morally and psychologically disabled or damaged from prior life experiences that they talk about to each other when things go wrong and they question their blind faith in their leader; and when the thrill of the hunt, pumping them with a faux sense of power, falters.

They turn on one another after one of them shoots a child who had been playing an "I dare-you" game of walking into the scary darkness. The child's murder brings to the surface their own moral limits and inability to stay "in character" in the game. The shooter invokes a series of mitigations: that the child was older or could have been armed, or he thought the flashlight was a gun. Another insists it was beyond the moral pale ("not what I signed up for"). The German-American trying to quell the erupting conflict notes the irony that the shooter is a human resources manager for a supermarket and the other a correctional officer in a state prison. What an upside-down world. But he himself is offended when the correctional officer calls him a Nazi for playing down the boy's age, and shoots the latter in his bullet-proof vest, knocking his breath out of him. "Next time, you want to piss somebody off, don't use those stupid cliches". It is an interesting comment reflecting also on the genre film forms and their potency (or not) for cultural critique and politics.

One of the shooters later will provide a notational contrast between Brazilian and American justifications of violence. After his divorce, he was so enraged, he took his guns and headed for a local mall to shoot it up, but, pointing to the sky, could not bring himself to do it; but now "God has given me the opportunity to deal with the pain here". There is more to be said about the safari subplot and its play with high-tech shooting (silencers, machine guns, telescopic gun scopes), with babe/ With her brown hair, dark sultry eyes and slender pink lips/ She'll give you killer coitus/ and claim you were never near her hips/ Those folks from down south/ Get no sleep and less sun/ They all learn to fish without hook, line or fun/ Acting like cocks of the walk/ They don't know São Paulo's a powder keg". It is the reference to São Paulo that makes the young man say worriedly to his female partner, "they know I'm from São Paulo”.

Images 22 and 23: Capoeira war dance; defenders from bunker

27 For more information, visit: https://www.humanesociety.org/resources/internet-hunting-fact-sheet and https:// www.fieldandstream.com/ virtual-long-shot-hunting-texas-whitetails-from-computer/. 
the "rules" of what are defined as games set apart from other human interaction ("technically we are not here, we have papers to prove that"), and violations of game rules ("we only use vintage weapons" [it is the villagers who only have vintage weapons, while the shooters are aficionados of the latest technology], "we only kill 'others' not our own"), the use of alienating language (the targets are not "people" but "locals", the paid collaborators are not people but contractors).

Evil is also located in the Mayor who in the end is stripped, a devil's mask put over his head, seated backwards on a donkey, and led out into the dry thorny caatinga (in Tupi: white vegetation) of pale withered trees and cacti; and in the German-American leader of the safari, played by steel-blue eyed Udo Kier toying (explicitly in the film) with Nazi associations who is entombed alive, underground, another image of evil temporarily under wraps. Blue-eyed people, former President Lula once exclaimed, were responsible for the 2008 financial crisis, and blue eyes, claims at least one Brazilian anthropologist, are often cinema or popular culture attributes of villains marking whiteness over blackness, wealth over poverty, colonizers over colonized and so on in a semiotic chain ${ }^{28}$.

Bacurau turns popular entertainment and genre forms into a museum of invokable cultural politics: tokens of resistance and identity fused out of solidarity. It can, of course, be enjoyed otherwise as a fevered dream, Wild West shoot-em-up, spaghetti Western, Tarantino pulp fiction, or Mad Max genre film (some of the tropes invoked by reviewers). Mendonça himself talks of the "classic American films" that he trained himself on, singling out John Carpenter, his ability to tweak the mundane into something surprising, "his amazing visual style, his Panavision shots, and his sense of rhythm and menace", also his political films,... But I really think about his style and his sense of menace and space" (Laly, 2020). It was the sense of menace, he says, that he didn't quite perfect in Neighboring Sounds and Aquarius, and that he thinks he's perfected in Bacurau. He acknowledges that it is genre-wise an "all-out classic western setup, which also came from my and Juliano's love for the best American films of the '70s... Michael Cimino, [Sam] Peckinpah, [John] Carpenter, John McTiernan... [Sergio] Leone and Corbucci from the Italian side, and of course Brazilian cinema from the " 60 s, which is one of our best vintage periods" (ibid.).

Cinema Novo and the Tropicalia movement are not only sources but clearly referenced in Bacurau. Cinema Novo assimilated ideas from Italian neo-realism and French auteur New Wave. Tropicalia reveled in antropofagia (cultural canabalism) mixing genres and styles from around the world, metabolizing them into something distinctively Brazilian ${ }^{29}$. Among the singers of Tropicalia were Caetano Veloso and Gal Costa who open the film Bacurau as the camera zooms in from the stars to a view of the blue earth from a satellite to a view of a solar panel winged satellite (perhaps the Hubble telescope) to the shoulder of South America to Brazil's northeast. The costuming of Lunga may well be a nod to the rock music group Os Mutantes associated with the Tropicalia musicians, Caetano Veloso, Gilberto Gil, and Gal Costa; and to Veloso's early interest in anarchistic "happenings". A song from Geraldo Vandré, a musician from the Northeast whose spirited song
28 I am indebted for this to one of the anonymous reviewers of this essay for this journal.
29 Named after Oswaldo de Andrade's 1928 Manifesto Antropofágico and Helio Oiticica's 1967 Tropicália. See also Schwarz for an inventive contemporary use of the antropofagia idea (2012). 
Caminhando became an anthem against the military dictatorship, closes the film.

Already with his earlier films Mendonça says: “I wasn't interested in making this $100 \%$ realistic kitchen sink kind of realism [British or Italian style]... I wanted to make a film that was a lot of fun to shoot. Each scene had to be fun" (Sbrizzi, 2012). He was interested, among other things, in playing with local urban legends, such as the spider boy in Recife who liked climbing buildings on the outside, entering apartments and falling asleep there without any robbery intent. He shot scenes on the street on which he lived, saying, "In editing, if you have a lot of time, you can actually play with interesting ideas"(ibid.), or also in shooting by moving the camera just slightly. Opposed to using the hand-held camera, his ambition was to screen his films in "the best large-scale classic cinemas in the world. The State Theatre in Sydney, the Lumière in Cannes, Alice Tully Hall in New York City, the Luxor in Paris. And the São Luiz theater (in Recife, Brazil), a thousand-seat, 1952 movie palace, which is the top-grossing cinema in the country for Bacurau" (ibid). Bacurau sold nearly 150,000 tickets in its first week and has continued to show despite the pandemic (Rubenstein, 2020). In the United States it was released only in March 2020 just as the pandemic closed cinemas, but it nonetheless has a 91\% on Rotten Tomatoes, is available on streaming platforms, and hopes for selection for the Oscars remaining up in the $\operatorname{air}^{30}$.

The film opens and closes with anthems of Brazilian music and cultural history. It opens, as noted above, with Caetano Veloso's love song Não identificado (Not Identified), sung in a beautiful melancholy voice by Gal Costa presaging a series of images and themes in the film: not identified (not on the map, unidentifiable objects or UFOs, semantic slippages); the ironic use of "simple" (just a simple Brazilian song, impoverished back country, simple people who don't mind being impoverished or repressed); anticomputer and flying disc new technologies (flying saucers, music discs, computer jamming); shared fantasy and hallucinatory worlds in one's head (outer space and inner city) - a love song:

I'll make a song for her/A simple, Brazilian song/ To launch after the carnival/ I'm going to do a romantic iê-iê-iê A sentimental anticomputer/ I'll make a love song/To burn a flying disc/ A song saying everything to her/ That I'm still alone, in love/ To launch into outer space/My passion will shine in the night In the sky of an inner city/As an unidentified object

And ends with the Geraldo Vandré song Réquiem Para Matraga in the Cinema Novo "Western" film by Roberto Santos:

I came here just to say/Nobody will shut me up/ If someone has to die/ May it be better/So much life to live/So much life to end/ With so much to be done/ With so much to save/ You who didn't understand me/ You don't lose by waiting.
30 See article in O Globo, October 8, 2020 (Heli de Almeida, 2020) reporting that the American distributor, Kino Lorber, will dispute the Brazilian commission's decision to not place Bucurau in contention, and nominate it in all categories itself. This is possible under the new rules of the Academy Awards. Meanwhile Bacurau won the Grand Prix of Brazilian cinema in October 2020. Available at: https://cultura.estadao.com.br/ noticias/cinema,bacurau-vence-o-grande-premio-do-cinema-brasileiro-veja-a-lista-dos-ganhadores, 70003472323 ?utm source=estadao: mail\&utm_medium=link 
Juliano Dornelles says of this song and the story behind it:

Matraga rediscovers his violent past and abuse when he needs justice. Just like Acácio (Pacote), who needs to defend his village with the same violence. Geraldo Vandré's beautiful music was composed for Matraga, a requiem we borrowed to accompany Acácio's return to the violent universe that he so wanted to leave behind (Lincoln Center, 2020).

Mendonça, too, resonated with the aesthetic fit: "I remember the day Juliano brought the theme song by Geraldo Vandré and we listened to it at the editing: 'Réquiem Para Matraga. It fit right in, as music, editing, and feeling carried over from this classic film”' (ibid.).

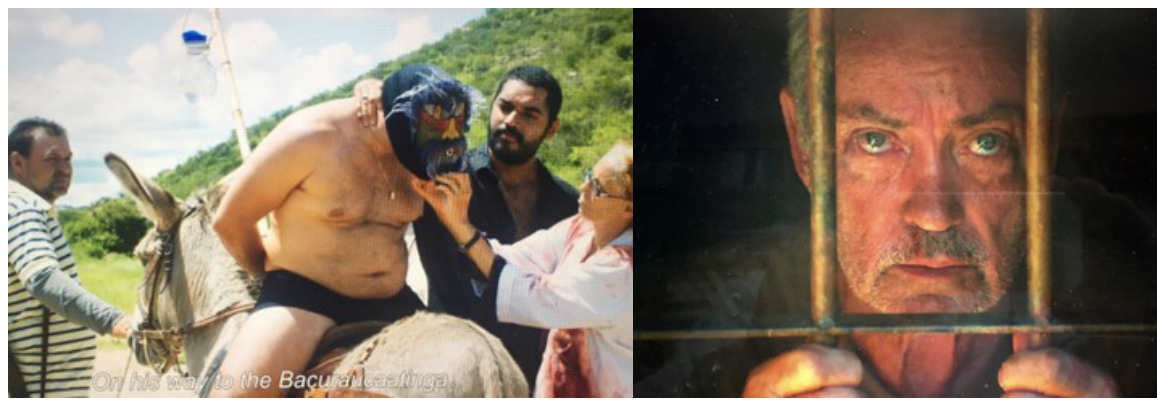

\section{Conclusion}

The point here is to illustrate a moment in the hinge of history, where the flow of enactments, representations, and different discourses and perspectives (what does "ethnographic" mean, to whom, for what purposes, reasons, or goals?) is always already both transnational, transversal, intersectional, class and diversity-sensitive; and also possibly signaling structural struggles (managing class and regional forces) and transformations (from an agrarian and late industrial modes of production of the long Holocene into the Anthropocene), by way of wild expenditures (on gaming, on drugs; on the technological utopias opposed by demotic frictions and counter-mobilizations at local scales). The big issues at play need not obviate the use of play and fun ("I wanted to make a film that was fun to shoot"; "In editing... you can play with interesting ideas"), for it is in play and fun that often new protocols for action emerge, and in which one can find the alarms and alerts that flip the switch back and forth between power politics and mythic-rhetorical frameworks on the one hand, and re-establishing more nurturing, intersectional, and open-ended solidarities on the other hand. The strong female characters in the film provide wacky and endearing demonstrations of these nurturing solidarities: Carmelita, the 94-year-old grandmother of villagers dispersed around the world; Teresa, who returns for Carmelita's funeral with vaccines and anti-phallic serum and tames the macho alpha male (Acácio); the nudist wife of the hallucinogenic sage who after wounding a shooter organizes taking her to the doctor; and, of course, the doctor Domingas, who expresses the
Images 24 and 25: Sending the Mayor into the desert; Entombing the lead shooter 
rage of loss of her "friend" (former lover?) at the funeral ${ }^{31}$, provides solace to the village girls, and in a three-witches-of-Macbeth-like scene faces off the GermanAmerican leader of the shooters.

The Anthropocene is one of the names for today's alerts or fire alarms on this larger scale of today's historical horizon, signaled in Bacurau by the struggle for water, Brazil's polarized politics (like that in the U.S. and many other countries), and, in the quarantine public service announcement, issued in April 2020 by the cast, pleading with people to stay at home during the Covid-19 pandemic to break its spread, mimicking the withdrawal into their house of the people of Bacurau as a mode of solidarity to reject the arrival of the pestilent mayor and the insistence by Bolsonaro that such action is not necessary. It is the same scene, instantly recognizable with the town crier, DJ Urso, holding his microphone, powered by his truck's battery, in the same way as in the film:

Avoid crowds, don't leave home. We need to be strong. Stay tuned to the other. With solidarity, effort, calm, and tranquility we will get through this one, you know. It is important to stay tuned to this warning. Let's do it like in the movie. Let's imitate art. Bacurau got organized and rid itself of a great burden. We will do the same ${ }^{32}$.

Each of the twenty-six members of the cast shorn of make-up and costume repeats the message: please stay at home ${ }^{33}$.

The Anthropocene, we tell ourselves, is a phase transition into a new planetary condition, one that might either reteach us the virtues of Indigenous or quilombo living-with and protecting-repairing the land, or, require the human species to migrate into space or radically evolve into something physically different, while still, we hope (or have no way to otherwise project and think) maintaining a form of compassion and moral fitness that is not just absorbed into larger flows and configurations of bits and atoms, but one that can attune to new biochemical ecologies and interspecies relations while maintaining what we call humanity. The current pandemic can be a workspace, in the meantime, for the future, as during and after the Great Plague (1665-66) was also "the beginning of a scientific renaissance in England" (Newitt, 2020) ${ }^{34}$.

Perhaps we too are learning things about viruses, biosystems, geology, ecology, molecular biology, and species interactions, and the unsocial sociabilities of human beings, that may serve us well in the near future, while we attempt in our Bacurauan, human way, to learn to live with ourselves. The social drama of Bacurau as well as the film text are both modes of exercising the moral imagination, of a time-out to see beyond the cynical constraints of reducing the world to the given, but seeing the solidarities that might be built across all our character flaws, differences, and peculiarities, including radically different ways of understanding our multiple natures.
31 At breakfast the morning after the funeral, Domingas is shown sitting in a chair staring at a letter or something, and then we are shown a photograph of two young women sitting side by side holding hands, who seem to be Carmelita and Domingas, and would explain also Carmelita's son, Plinio, incorporating Domingas cursefilled harangue in his welcome and celebration of Carmelita's life as her understandably being emotional. Towards the end of the film, Domingas returns to the village and a young woman runs up to her and hugs and kisses her saying, "You are crazy", in an apparent reference to facing off the German-American, perhaps another non-normative cross-generational love passing on, one of many non-normative relationships embraced in the "quilombo" refuge.

32 Available at: https:// telepadi.folha.uol.com.br/ kleber-mendonca-simula-campanha-fiqueemcasa-com-cenasde-bacurau/

33 Bolsonaro, on 18 Sept 2020 flew to an area of the Amazon with fires and smoke so thick that at first his plane could not land, but then he gave a Trump-like speech claiming Brazil's response to Covid-19 was the best in the world, and that staying at home was for the weak. Available at: https:// brazilian.report/coronavirus-brazil-live-blog/2020/09/18/ brazil-jair-bolsonaro-staying-home-weak/ and https://tv6. news/jair-bolsonaro-staying-home-because-of-the-coronavirus-is-for-the-weak/;https://www. time24.news/2020/09/bolsonaro-says-staying-at-home-in-the-pandemic-is-for-weak.html.

34 Isaac Newton "sheltered in place" on his estate safely outside London, while in London doctors experimented with systematic searching out of the sick, quarantining, and disinfecting homes with lime. King Charles II ordered a halt to public gatherings including funerals in 1666. He had sanctioned the founding of the Royal Society in 1660 and two members of the Society, Robert Hooke in 1665, and Antoni van 


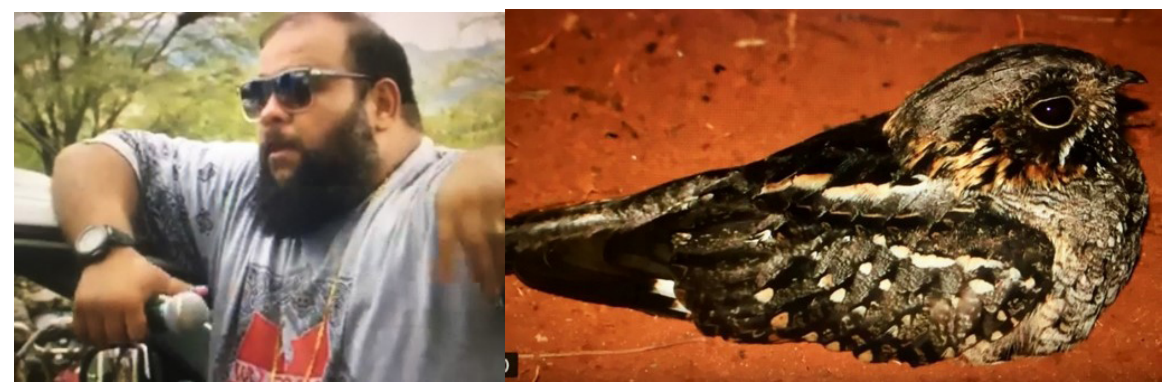

Recebido: 05/10/2020

Aprovado: $15 / 10 / 2020$
Leeuvanhoek in 1674 and 1683 began discovering microorganisms (fungi, protozoa, bacteria). Today it is genomics that allows establishing the connections between viruses and animal hosts and differentiating between forms of coronaviruses such as SARS which was a global pandemic in 2003-4 and the SARS-CoV-2 or Covid-19 in 2019-20.

Images 26 and 27: DJ Urso and the Bacurau 


\section{References}

ALMEIDA, Ronaldo de. Bolsonaro, the Evangelicals and the Brazilian Crisis, [s. I.], 2020. Available at: https://culanth.org/fieldsights/series/bolsonaro-and-the-unmaking-of brazil. Accessed on: 8 nov. 2020.

BACURAU, Press Conference. Cannes: Festival de Cannes (Officiel), 2019. Available at: https://www.youtube.com/watch?v=A16tLglxCW8. Accessed on: 8 Nov. 2020.

BLOCH, Arnaldo. In 'Bacurau', Kleber becomes a Tarantino from the western Pernambuco. O Globo, [s. l.], 12 Aug. 2019. Available at: https://oglobo.globo.com/cultura/ em-bacurau-kleber-vira-um-tarantino-do-faroeste-pernambucano-23872799. Accessed on: 8 Nov. 2020.

BISPO DOS SANTOS, Antonio. Colonização, Quilombos: Modos e Significações. Brasília: Instituto de Inclusão no Ensino e na Pesquisa, 2015.

BITTENCOURT, Ela. Interview: Kleber Mendonça Filho and Juliano Dornelles. Film Comment, [s. l.], 2019. Available at: https://www.filmcomment.com/blog/cannes-interview-kleber-mendonca -filho-and-juliano-dornelles/. Accessed on: 8 Nov. 2020.

BORGES, Antonáia; SOBRAL, Roberto. Universities as a Battlefield in Brazilian Politics Today. Cultural Anthropology Field Sites, [s. I.], 2020. Available at: https://culanth.org/ fieldsights/series/bolsonaro-and-the-unmaking- of-brazil. Accessed on: 8 Nov. 2020.

BRANFORD, Sue; TORRES, Mauricio. Brazil sees growing wave of anti-indigenous threats, reserve invasions. Mongabay, [s. l.], 19 Feb. 2019. Available at: https://news. mongabay.com/2019/02/ brazil-sees-growing-wave-of-anti-indigenous-threats-reserve-invasions/. Accessed on: 8 Nov. 2020.

BRAZIL'S star justice minister Sergio Moro resigns in blow to Jair Bolsonaro. The Guardian, [s.l], n.p., 24 Apr. 2020. Available at: https://www.theguardian.com/world/2020/ apr/24/brazil-justice-minister-sergio-moro-resigns-jair-bolsonaro. Accessed on: 8 Nov. 2020.

CABRAL DE OLIVEIRA, Joana; MARINI, Marisol. Why is Bolsonaro Afraid of Anthropology? Cultural Anthropology Field Sites, [s. l.], 2020. Available at: https://culanth.org/ fieldsights/series/ bolsonaro-and-the-unmaking-of-brazil. Accessed on: 8 Nov. 2020.

CESARINO, Leticia. What the Brazilian 2008 Elections Tell Us About Post-Truth in the Neoliberal Digital Era. Cultural Anthropology Field Sites, [s. I.], 2020. Available at: https:// culanth.org/fieldsights/series/bolsonaro-and-the-unmaking-of-brazil. Accessed on: 8 Nov. 2020.

COYLE, Jake. In Cannes, a gory Western stands against Bolsonaro's Brazil. APNews, [s. I.], 16 May 2019. Available at: https://apnews.com/30ffa13a136049de87e56a8e7e2e5a77. Accessed on: 8 Nov. 2020.

DEBURGE, Peter. Film Review: “Bacaurau”. Variety, [s. l.], 15 May 2019. Available at: https://variety.com/2019/film/reviews/bacarau-review-1203215347/. Accessed on: 8 Nov. 2020.

ESCOREL, Eduardo. Bacurau - celebration of barbarism: film exalts unsettling partnership between unassisted people and bandits. Piauí. [S. I.], 28 Aug. 2019. Available at: piaui.folha.uol.com.br/bacurau-celebracao-da-barbarie/. Accessed on: 8 Nov. 2020.

ETHNOGRAPHIC Views of Brazil's (new) Authoritarian Turn. HAU: Journal of Ethnographic Theory, v. 10, n. 1, p. 7-11, 2020. Available at: https://www.haujournal.org/index. php/hau/issue/view/ hau10.1. Accessed on: 8 Nov. 2020. 
FISCHER, Michael M. J. Bombay Talkies, the Word \& the World: Salman Rushdie's Satanic Verses. Cultural Anthropology, [s. l.], v. 5, ed. 2, 1990.

FISCHER, Michael M. J. In the Science Zone: the Yanomami and the Fight for Representation. Cultural Anthropology, Anthropology Today, [s. l.], v. 17, ed. 4, p. 9-14, 2001.

FISCHER, Michael M. J. Amazonian Ethnography and the Politics of Renewal. In: Anthropology in the Meantime: Experimental Ethnography, Theory and Method for the Twenty-First Century. Durham: Duke University Press, 2018. cap. 5.

FISCHER, Michael M. J. Iran and the Boomeranging Cartoon Wars: Can Public Spheres at Risk Ally with Public Spheres Yet to be Achieved? Public Culture, [s. I.], v. 5, ed. 1, p. 27-62, 2009.

FREYRE, Gilberto. The Masters and the Slaves. New York: Alfred A. Knopf, 1933 [1956].

GLUCKMAN, Max. Order and Rebellion in Tribal Africa. Glencoe: Free Press, 1963.

HALLOY, Arnaud. Gods in the Flesh: Learning Emotions in the Xangô Possession Cult (Brazil). Ethnos, [s. I.], v. 77, ed. 2, p. 177-202, 17 Jul. 2012.

HELI DE ALMEIDA, Carlos. "Bacurau” no Oscar? Distribuidora americana quer emplacar filme nas categorias principais da disputa: [In English: "Bacurau" at the Oscars? American Distributor Wants to Place Film in the Main Categories of the Dispute]. 0 Globo, [S. l.], n.p., 8 Oct. 2020.

HUNT, Daniel. Film Review: Bacurau. In: Brazil Wire, [s. l.], 31 Aug. 2019. Available at: https://www.brasilwire.com/bacurau/. Accessed on: 8 Nov. 2020.

KIRPATRICK, David D.; LEON CABRERA, José María. How Trump and Bolsonaro Broke Latin America's Covid-19 Defenses. The New York Times, [S. I.], v. 6, n. 7, 27 Oct. 2020. A1, n.p. Available at: https://www.nytimes.com/2020/10/27/world/trump-bolsonaro-coronavirus-latin america.html. Accessed on: 8 Nov. 2020.

LEINER, Piero. Hybrid Warfare in Brazil: The Highest Stage of Military Insurgency. HAU Currents: The Rise of Brazilian Fascism, [S. l.], n.p., 27 Oct. 2020. Available at: https:// www.haujournal.org/ index.php/hau/issue/view/hau10.1. Accessed on: 8 Nov. 2020.

LONDONO, Ernesto. A Year After Her Killing, Marielle Franco Has Become a Rallying Cry in a Polarized Brazil. The New York Times, [S. I.], n.p., 14 Mar. 2019. Available at: https://www.nytimes.com/2019/03/14/world/americas/marielle-year-death.html. Accessed on: 8 Nov. 2020.

MAPPING BACURAU: THE HOUR AND TURN OF AUGUSTO MATRAGA, 2020, Lincoln Center. Program Notes [...]. [S. l.: s. n.], 2020. Available at: https://www.filmlinc.org/films/ the-hour-and-turn-of-augusto-matraga/. Accessed on: 8 Nov. 2020.

MCCOY, Terrance. In Brazil, the death of a poor black child in the care of rich white woman brings a racial reckoning. The Washington Post, [S. l.], n.p., 28 Jun. 2020. Available at: https://www.washingtonpost.com/world/the_americas/brazil-racism-black-lives-matter-miguel-otavio-santana/2020/06/26/236a2944-b58b-11eaa51055bf26485c93_story.html?utm_campaign=wp_post_most\&utm_medium=email\&utm_source=newsletter\&wpisrc=nl_most. Accessed on: 8 Nov. 2020.

MOURA FAGUNDES, Guilherme. Reclaiming Quilombismo in the End of Conciliations. Cultural Anthropology Field Sites, [s. l.], 2020. Available at: https://culanth.org/fieldsights/series/ bolsonaro-and-the-unmaking-of-brazil. Accessed on: 8 Nov. 2020.

NASCIMENTO, Abdias do. O Quilombismo. Rio de Janeiro: Fundação Palmares/OR Editor Productor Editor Neiburg, Federico and Omar Ribeiro Thomaz, 2002.

PHILLIPS, Tom. Marielle Franco: Brazil's Favelas Mourn the Death of a Champion. 
Michael M. J. Fischer

The Guardian, [s.l], n.p., 17 Mar. 2018. Available at: https://www.theguardian.com/ world/2018/mar/18/ marielle-franco-brazil-favelas-mourn-death-champion. Accessed on: 8 Nov. 2020.

RUBENSTEIN, Bessie. Drag Artist Silvero Pereira on Getting Blood-Soaked in Bacurau. Interview Magazine, [s.l], n.p., 6 Mar. 2020. Available at: https://www.interviewmagazine.com/film/ silvero-pereira-bacurau. Accessed on: 8 Nov. 2020.

SBRIZZI, Paul. A Conversation with Kleber Mendonça Filho (Neighboring Sounds). Hammer to Nail, [s.l], n.p., 6 Apr. 2012. Available at: https://www.hammertonail. com/interviews/a-conversationwith-kleber-mendonca-filho-neighboring-sounds/. Accessed on: 8 Nov. 2020.

SCHWARCZ, Lilia M. I Was Cannibalized by an Artist. In: BIEHL, Joao; LOCKE, Peter (Eds.). Unfinished: The Anthropology of Becoming. Durham, N.C.: Duke University Press, 2017.

SCHWARTZMAN, Simon. Force de foco: diversidade e identidades étnicas no Brasil. Novos Estudos CEBRAP, v. 55, p. 83-96, 1999.

SHOARD, Catherine. "Brazil is not a Democracy": Cannes Contender's Cast Stages Red Carpet Protest. The Guardian, [s.l], n.p., 17 May 2016. Available at: https://www. theguardian.com/film/2016/may/17/brazil-is-not-a-democracy-aquarius-premiere-cannes-red-carpet-protest. Accessed on: 8 Nov. 2020.

SOLANAS, Fernando; GETINO, Octavio. Towards a Third Cinema. In: NICHOLS, Bill (Ed.). Movies and Methods: An Anthology, p. 44-64. Phoenix: University of Arizona Press, 1976 [1969].

TADDEI, Renzo; BULAMAH, Rodrigo C.; SCHAVELZON, Salvador. Bolsonaro and the Unmaking of Brazil. Cultural Anthropology Field Sites, [S. l.], 2020. Available at: https:// culanth.org/ fieldsights/series/bolsonaro-and-the-unmaking-of-brazil. Accessed on: 8 Nov. 2020.

THE DIRECTORS of Bacurau \& Sônia Braga on the Making of Their Brazilian Thriller. Mendonça Filho, Kleber and Jiuliano Dornelles. New York City: Film at Lincoln Center, 2019. Available at: https://www.youtube.com/watch?v=-z51vOSxus8. Accessed on: 8 Nov. 2020.

TURNER, Victor. Schism and Continuity in An African Society. New York: Berg, 1957.

ZIGONI, C. (English translation). We Belong to the Land. In: AGITATE! Blog, [s. I.]: 2020. Available at: http://agitatejournal.org/we-belong-to-the-land. Accessed on: 8 Nov. 2020 . 